\title{
The coming of the railways to Scandinavia, Hans Christian Lumbye and others
}

Norway and Sweden both came late to railway building. In 1845 the Swedish count Adolf Eugene von Rosen had received permission to build railways in Sweden but his money ran out and the Swedish parliament decided that the trunk lines should be built and operated by the state. In 1854, the naval engineer Nils Ericson was employed to oversee the project. The first Norwegian line opened in 1854 (Christiana to Eidsvoll) and the first steam powered Swedish lines opened in 1856 (Nora to Ervalla) and 1857 (Arboga to Köping). The first two main lines were completed between 1860 and 1864 - the Southern, stretching from Stockholm to Malmö in the south, and the Western, which went to Gothenburg in the west.

When the Helsinki and Hämeenlinna line opened in 1862, Finland was then the Grand Duchy of Finland, a territory of Imperial Russia; consequently the railways were built to the Russian broad track gauge rather than the standard European gauge. By 1900 most of the main lines had been built, including the line to St. Petersburg.

Technically it could be said that the Danish railway began in 1844 with the opening of the Kile-Altona line in Holstein by King Christian VIII on 18 September 1844. However, as a result of the Second Schleswig War, Holstein was ceded to the German confederation in 1864 and it became a German railway although it had been built under the Danish monarchy. It could be argued that the true history began three years later with the opening of the line between the capital Copenhagen and the cathedral city of Roskilde. The Copenhagen-Roskilde line was inaugurated as the first in Denmark, on 24 June 1847. The construction was led by the English engineer William Radford and the Manchester-based Sharp Brothers and Company built the first batch 
of locomotives, the five ODIN locomotives. The original intention had been for the line to go from Copenhagen to Korsør on the west coast of Zealand and, when the funding had been secured, the line was extended to Korsør in 1856. ${ }^{1}$

One of the first Scandinavian railway pieces Malmö Järnbanesång (Malmö Railway song) was composed for the inauguration of the Lund-Malmö railway in 1856 by the Swedish composer Otto Lindblad (1809 - 1864). Fifteen years later it was a cause for celebration when Sweden and Norway were finally connected by rail and this was marked by Traugott Grahl in his piece Sveas belsning till Nore, Walzer (Greetings from Sweden to Norway, Waltz). The piece opens with a slow lyrical passage with woodwind and brass soloists in dialogue with the strings leading to the main waltz section which alternates between cheerful melodies and more melancholic passages.

Along with the waltz and the polka, the galop was one of the most popular ballroom dances in the nineteenth century. It is therefore no surprise that three of the pieces composed in celebration of the opening of Scandinavian railway lines were in this form. Jean Meyer, a violinist at the Stockholm Royal Opera House, wrote the Jernvägs-Galopp (Railway Galop) for the inauguration of the Stockholm to Gothenburg line. Jernban-Galopp (Railway Galop) by the little-known composer Franz Hoyer was composed for the inauguration of Finland's first railway and Hans Christian Lumbye's Copenhagen Steam Railway Galop was composed to celebrate the opening of the line from Copenhagen to Roskilde.

The galop is a fast, lively dance with two beats in a bar, its name comes from the galloping movement of horses. It was a simple but energetic dance to perform: dance partners galloped down the ballroom with springing steps. Because it was such a physically-demanding dance, galop pieces were usually quite short. Galops usually follow the same musical form which includes an introduction, trio and a finale (or coda) as well as the galop section itself. Each of the composers takes the opportunity to build up the excitement in the introduction as the train gathers speed and sets off. Meyer's Railway Galop opens with a rising figure on the strings, getting gradually faster before we hear the galop theme proper. He creates a convincing train imitation produced by sandpaper blocks. They are played with short strokes on the beat at first, getting faster as the train accelerates until a circular motion produces the sound of the train going at full speed - a process which is used in reverse as the train slows down at the end of the journey. Hoyer's opening music pictures the train starting up, gradually getting louder 
and faster as the train gathers speed, leading towards a light-hearted main galop theme. Both pieces make much use of flutes to suggest the sound of the train whistle, but what is unusual in Hoyer's train galop is an isolated dissonant passage where the flutes, glockenspiel and trilling triangles give way to strident brass and rumbling kettle drums in complete contrast to the carefree galop tune, perhaps emphasising the then inherent dangers of train travel. Unlike the pieces by Meyer and Hoyer which are largely forgotten, Lumbye's piece is still part of the orchestral repertoire and is explored in more detail.

\section{Hans Christian Lumbye}

The Danish composer Hans Christian Lumbye $(1810$ - 1874) had much in common with the Strauss family, in fact he is sometimes referred to as the Strauss of the North. He was a prolific composer of waltzes, polkas, galops and marches and made a career conducting his own orchestra in concerts of light music, mainly at the Tivoli Gardens but also, for one season at Pavlosk where members of the Strauss family had been such a success. Just as the Strauss family played a large part in creating the demand for light and accessible entertainment music, Lumbye was a very important figure in the creation of popular musical culture in Northern Europe.

He started his career playing trumpet in military bands and served in the Horse Guards in Copenhagen. Then in 1839 he heard an Austrian band playing pieces by Lanner and Strauss. This was the first time such pieces had been heard in Scandinavia and Lumbye was so impressed that in 1840 he formed his own light music orchestra and performed his first 'Concert à la Strauss' at the fashionable Raus Hotel in Copenhagen. He soon became a popular conductor in theatres around Copenhagen gaining a reputation as Scandinavia's undisputed leading dance composer. In 1843 the Tivoli Garden opened in Copenhagen. The now famous amusement park and pleasure gardens were originally named the Tivoli and Vauxhall, a reference to the Tivoli gardens in Paris and Rome and the London Vauxhall Pleasure Gardens. Lumbye was engaged as music director, in-house composer and leader of the concert hall's orchestra, a position he held for the next 30 years. There he composed about 700 dances, mainly polkas, waltzes and galops with several of them reflecting the connection with Tivoli such as Tivoli Shooting Gallery Galop, Tivoli Bazaar 
Galop and Tivoli Steam Merry-go-round Galop. He also composed more than 25 ballet divertissements working in collaboration with the choreographer August Bournonville. Lumbye soon became a big draw to the Tivoli crowds, but also undertook a long series of tours visiting Hamburg, Berlin, Vienna, Paris, St Petersburg and Stockholm securing him an international reputation.

He remained a popular figure in the musical life of Copenhagen until his death in 1874. Two of his sons followed in their father's footsteps. Both Carl Lumbye (1841 - 1911) and Georg Lumbye (1843 - 1922) were successful conductors and composers of light music and both conducted the Tivoli wind band.

\section{Kjobenbavns Jernbane-Damp-Galop (Copenhagen Steam Railway Galop) - Hans Christian Lumbye}

Lumbye's Copenhagen Steam Railway Galop, a musical depiction of a railway journey, is one of his most famous and regularly performed compositions. The train sets off slowly out of the station, gradually accelerates, takes us on the course of the journey, and then slowly grinds to a halt. The piece is scored for a large orchestra with strings, woodwind and large brass and percussion sections. The orchestration includes several special train sound effects and, as the piece approaches the end, in performance some orchestral conductors announce that the train has reached its destination. Although performers of Strauss railway pieces often add their own train sounds, Lumbye's original score itself abounds with special effects. Towards the end of the Introduction there is part in the percussion section marked as glocken geleute (train bell) followed by an Eisenbabn pfeife (railway whistle). As the train starts to pick up speed in the next section the instruments chosen to imitate the train's rhythmic chugging are marked as 'sandpaper block plus springs plus bass drum'. Although sandpaper blocks and bass drum are not unusual choices to reproduce train sounds, the spring however is more unusual. The reco-reco is used to play this part today. It is a scraper of African origin, nowadays made of a metallic cylinder with springs attached and played with a metal stick. In Lumbye's time the spring specified would have been simply a real spring mounted with a resonator. In the final section we hear a conductor's whistle as marked in the score. As well as including these special effects, conventional orchestral instruments are also used to portray the sounds of a train: wide 
leaps and 'squeaks' marked in the flute, piccolo and oboe parts; long sustained notes in the horns; and rhythmic percussion parts.

The piece opens with a fairly slow Introduction, three in a bar, with a slow romantic melody on the cellos and oboe. Towards the end of the Introduction, twelve strikes of the train bell cut across the calm cello melody followed by five hoots on the train whistle and the music moves into a faster Allegretto section with two beats in a bar.

The sandpaper blocks, springs and bass drum imitate the acceleration of the train. As the train starts off they play on the first beat of the bar for four bars, then on both beats for two bars, then the two strokes increase to three, finally arriving at a regular four quavers in each bar, thus accurately encapsulating the acceleration of the train. At the same time the strings and woodwind play rapid semiquavers a semitone apart:

\section{Lively and getting gradually faster}
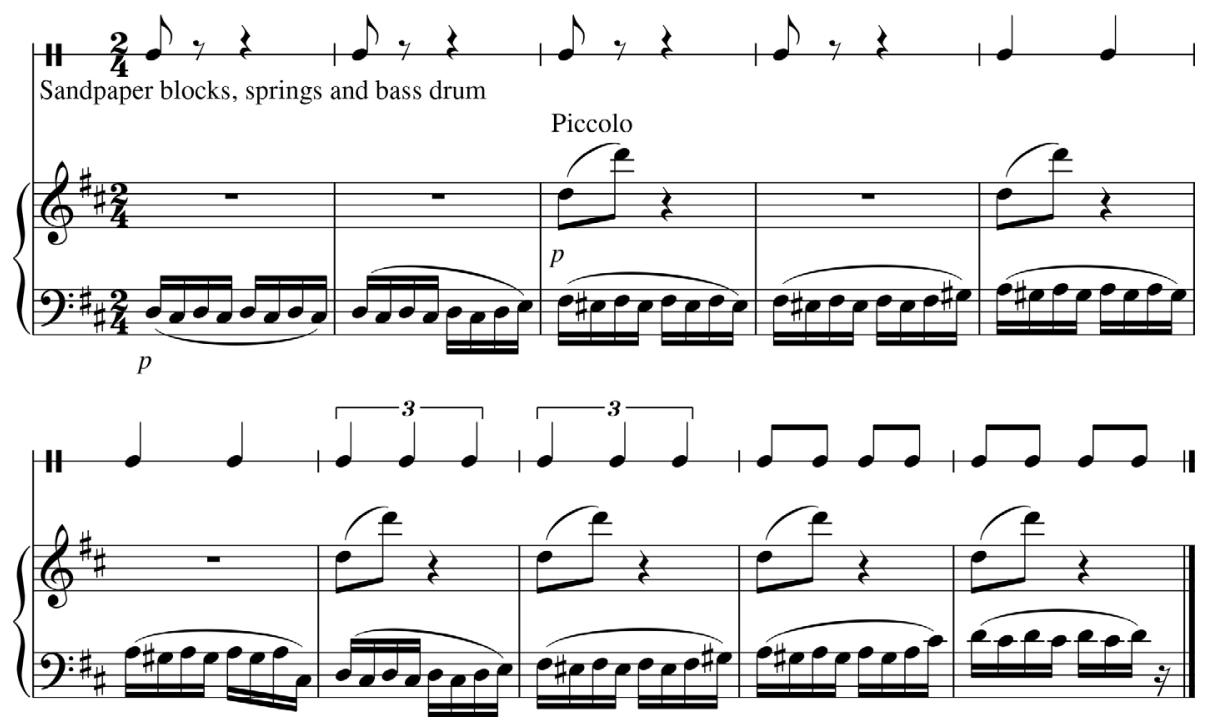
The music accelerates further to the fast main galop section based on this melody:

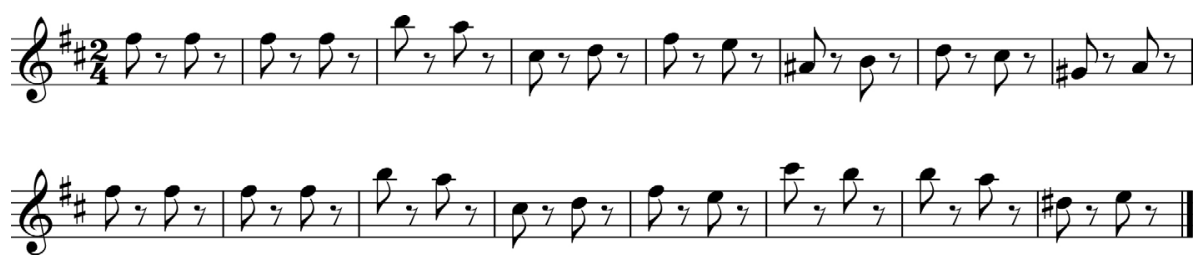

It then changes key for the slower moving Trio section:

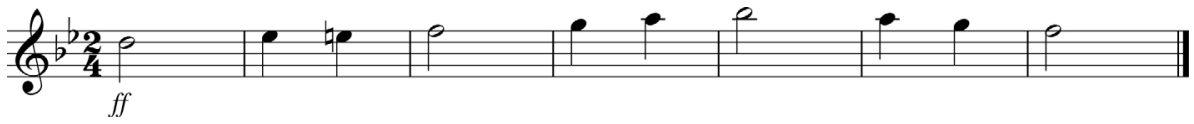

Some listeners may be struck by the similarity the melody bears to one of the main themes in Julius Fučík's famous Entry of the Gladiators. The two pieces use a different time signature, but both melodies move upwards in a scale wise movement over four bars and then descend for two bars:

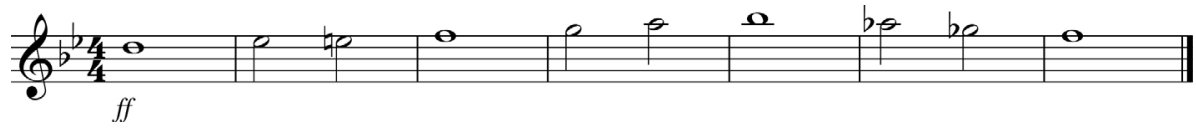

However, given the fact that the Railway Galop was composed in 1847 and the Czech composer Fuč́k was not born until 1872, any accusation of plagiarism cannot be levelled at Lumbye.

The final section, the Coda, opens with full orchestra and high swirling semiquavers in the woodwind and violins. As the train gradually slows down, the rapid semiquaver figure moves from the instruments' higher registers down to their lower registers, the tempo gets slower, the train whistle sounds and as the piece approaches the end, in some performances, the conductor announces that the train has reached its destination. The music gradually quietens down, with instruments dropping out in turn until only the lower strings are playing the semiquavers. The sandpaper block, springs and bass drum combination reappears for the final five bars and the music draws to a halt marked by a final loud chord played by the full orchestra.

Lumbye was a friend of the Hungarian composer and conductor Josef Gung'l and, although Gung'l was not Scandinavian, mention should be made here of his railway piece Eisenbahn-Dampf-Galopp (Steam Railway Galop) 
because of the similarity between this piece and Lumbye's Copenhagen Steam Railway Galop. Josef Gung'l (1809 - 1889) enjoyed a similarly popular career to Lumbye and the Strauss family, touring Europe and America with his light music orchestra as well as playing the summer seasons at Pavlosk between 1850 and 1855 . He too was a prolific composer of dance music with many successful works under his belt.

Gungl's Eisenbahn-Dampf-Galopp was instantly popular. A piano arrangement of the piece was published in Philadelphia, USA with the title 'Rail Road Steam Galop' and the added note 'as performed with unbounded applause'. A lithograph illustration of the railroad depot at Philadelphia is featured on the cover. The piano arrangement includes a stave for 'Locomotive Steam-Engine' with a repeated note on each beat of the bar, along with the instruction "The noise which is produced by the steam in the Chimney of a Locomotive, may be very naturally imitated by clapping the Hand on a Stove Door.'

It is interesting to compare the ways that Gung'l and Lumbye depict the train as it sets off. Both use a percussive line to imitate the rhythmic chugging of the train. As we have seen, Lumbye takes care to build the train's acceleration into the rhythm of the percussion line (see page 93) whereas Gung'l sounds claps on the first beat of the bar for three bars, with a pause in the first bar, and then settles on the same rhythm for the remainder of the piece (see below). Another feature that both pieces have in common is the use of rapid semiquavers a semitone apart to emulate the movement of the train.

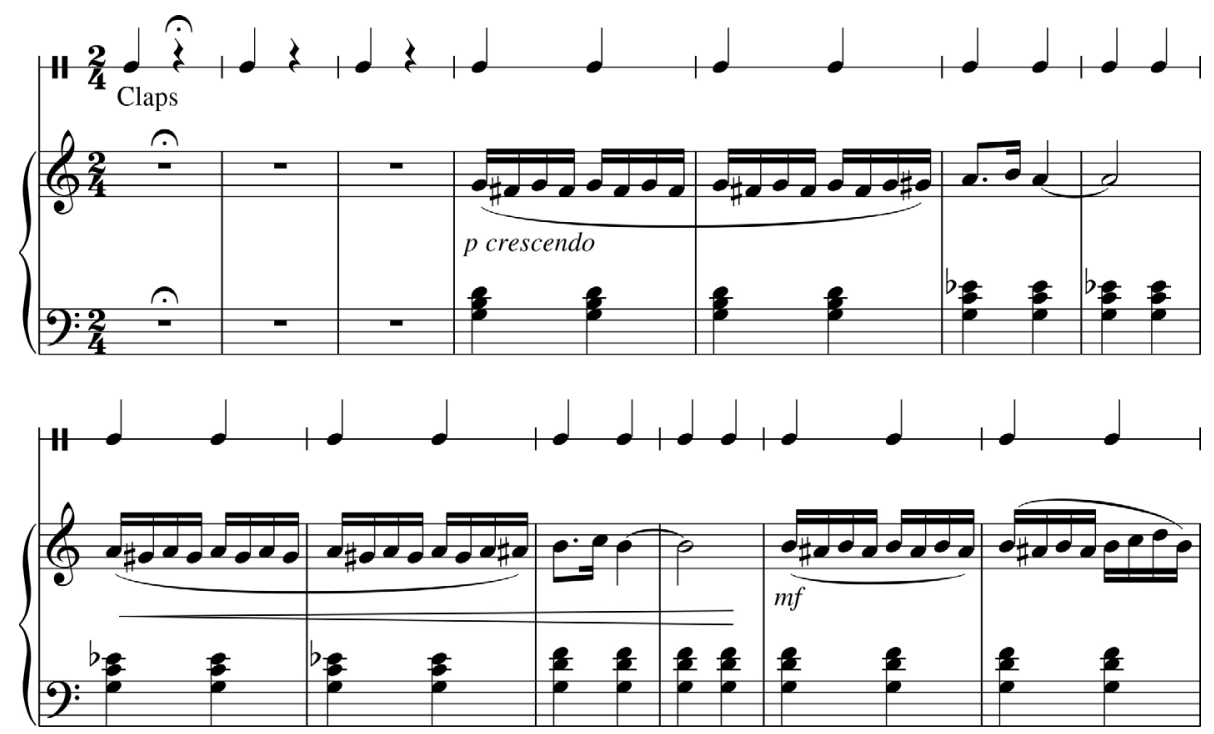


Lumbye would no doubt have heard of Eisenbahn-Dampf-Galopp and would certainly have been aware of its success. It had been played in Copenhagen by a visiting band from Steiermark in the spring of 1847 and it was not long after this that Lumbye composed his own railway galop. It could be argued that Lumbye was influenced by Gung'l's piece, although it should be noted that such rapid semiquaver movement is a common device found in many railway pieces to depict the movement of a train.

\section{Endnotes}

1 Christian Wolmar. The Golden Age of European Railways. (Barnsley: Pen \& Sword Transport, 2013): 237-241 